
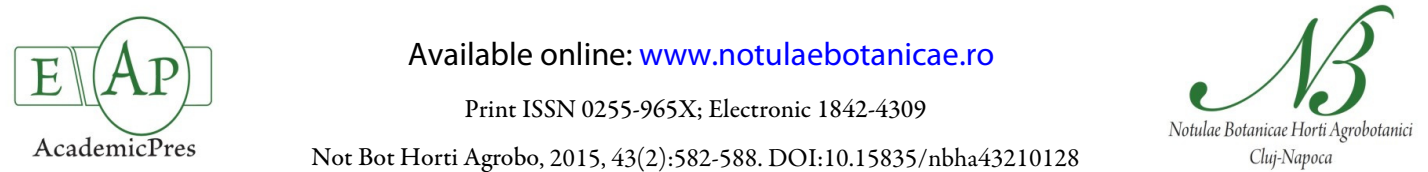

\title{
High Genetic Differentiation among European White Oak Species (Quercus spp.) at a Dehydrin Gene
}

\author{
Iacob CRĂCIUNESC ${ }^{1}$, Barbara VORNAM², Ludger LEINEMANN ${ }^{2}$, \\ Reiner FINKELDEY ${ }^{2,3}$, Neculae ȘOFLETEA ${ }^{1}$, Alexandru Lucian CURTU ${ }^{1 *}$ \\ ${ }^{I}$ Transilvania University of Brasov, Department of Forest Sciences, Şirul Beethoven 1, 500123, Braşov, \\ Romania; iacob.craciunesc@unitbv.ro;nic.sofletea@unitbv.ro; lucian.curtu@unitbv.ro("correspondingauthor) \\ ${ }^{2}$ University of Göttingen, Büsgen Institute, Section of Forest Genetics and Forest Tree Breeding, Büsgenweg2, 37077 Göttingen, \\ Germany;bvornam1@gwdg.de;lleinem@gwdg.de;rfinkel@gwdg.de \\ ${ }^{3}$ Kassel University, Möncheberzstr. 19,34125 Kassel, Germany
}

\begin{abstract}
Dehydryn genes are involved in plant response to environmental stress and may be useful to examine functional diversity in relation to adaptive variation. Recently, a dehydrin gene (DHN3) was isolated in Quercus petraea and showed little differentiation between populations of the same species in an altitudinal transect. In the present study, inter- and intraspecific differentiation patterns in closely related and interfertile oaks were investigated for the first time at the DHN3 locus. A four-oak-species stand (Quercus frainetto Ten., Q. petraea (Matt.) Liebl., Q. pubescens Willd., Q. robur L.) and two populations for each of five white oak species (Q. frainetto Ten., Q. petraea (Matt.) Liebl., Q. pubescens Willd., Q. robur L. and Q.pedunculiflora K. Koch) were analyzed. Three alleles shared by all five oak species were observed. However, only two alleles were present in each population, but with different frequencies according to the species. At population level, all interspecific pairs of populations showed significant differentiation, except for pure Q. robur and Q. pedunculiflora populations. In contrast, no significant differentiation $(\mathrm{p}>0.05)$ was found among conspecific populations. The DHN3 locus proved to be very useful to differentiate $Q$. frainetto and $Q$. pubescens from Q.pedunculiflora ( $\mathrm{F}_{\mathrm{ST}}=0.914$ and 0.660 , respectively) and Q. $\operatorname{robur}\left(\mathrm{F}_{\mathrm{ST}}=0.858\right.$ and 0.633 , respectively). As expected, the lowest level of differentiation was detected between the most closely related species, Q. robur and Q. pedunculiflora $\left(\mathrm{F}_{\mathrm{ST}}=0.020\right)$. Our results suggest that DHN3 can be an important genetic marker for differentiating among European white oak species.
\end{abstract}

Keywords: dehydrin gene, genetic differentiation, oaks, outlier loci

\section{Introduction}

The genus Quercus L. comprises roughly 500 species (Aldrich and Cavender-Bares, 2011) subdivided into several distinct monophyletic groups (Manos et al., 1999; Manos and Stanford 2001). Oaks are trees or shrubs which are found in evergreen or deciduous forests throughout the Northern Hemisphere, ranging from temperate to tropical or semi-arid regions (Nixon, 1993). Their high ecological and economic importance is well known (McShea et al., 2007; Aldrich and Cavender-Bares, 2011), being among the most notable forest trees. At the same time, oaks are among the most difficult to distinguish at the species level, mainly due to their phenotypic plasticity and capacity for interspecific hybridization (Gailing and Curtu, 2014). These Quercus features led to debate the biological species concept (Mayr, 1942) and to serve as a model in the development of species ecological concept (Van Valen, 1976).

In the last decade, due to great advances in genetic and molecular analysis, the main issue of differentiation between species has moved at the genome level. Thus, it was proposed that genes can be considered units of species differentiation $(\mathrm{Wu}$, 2001). In this model, the sympatric and interfertile species, as many oaks are, possess a genome with a mosaic of impermeable and permeable regions to gene flow. While the permeable ones share introgressed genes that decrease interspecific differentiation, the impermeable regions are responsible for the maintenance of species integrity because they accumulate divergence in response to selection. This theory is supported by several studies in interfertile plant and animal species (Barton and Gale, 1993; Via and West, 2008), as well as in the Quercus spp. complex (Scotti-Saintagne et al., 2004). From this point of view, one can better understand the antagonistic effects of interspecific gene flow and divergent selection which causes the low genetic differentiation between hybridizing oak species at most genomic regions and the high interspecific differentiation at several 'islands' (outlier regions), respectively. This pattern is consistent with the expected spatial clustering of outlier markers due to ecological speciation (Via, 2009). 
The outlier loci, closely linked or even directly under selection (Lind-Riehl et al., 2014), display significantly higher $\mathrm{F}_{S T}$ values than those expected under selectively neutral conditions, mainly due to different proportion of the alleles among the species (Muir and Schlötterer, 2005; Lind and Gailing, 2013). In addition, the genomic regions containing outliers between $Q$. petraea and $Q$. robur indicated lower recombination rates as compared to a control region (Goicoechea et al., 2012). Because such loci might be responsible for adaptive differences among oak species, their identification became very important for proper species assignment.

Initially, only few outlier markers exhibiting large species differences were found for isozymes (Gömöry, 2000), sequencecharacterized amplified regions (SCARs; Bodénès et al., 1997) or amplified fragment length polymorphisms (AFLPs; Coart et al., 2002; Mariette et al., 2002). However, $12 \%$ and $23 \%$ outliers out of a marker set were identified between Q. petraea and Q. robur in two genome-wide studies using multiple or single marker type, respectively (AFLPs, SNPs, SCARs, microsatellites and isozymes by Scotti-Saintagne et al., 2004; SNPs by Guichoux et al., 2013). High levels of interspecific differentiation were later reported by means of genomic (Curtu et al., 2007; Neophytou et al., 2010; Zeng et al., 2010; Curtu et al., 2011a; Neophytou et al., 2011; Goicoechea et al., 2012) or derived from Expressed Sequence $\mathrm{Tag}(\mathrm{EST}$ ) microsatellites (Lind and Gailing, 2013; Lind-Riehl et al., 2014) at different outcrossing Quercus species pairs. However, in many expressed loci the genetic differentiation was on the same level as at neutral loci, while adaptive loci and neutral ones seemed to have similar differentiation patterns among contrasting habitats (Quang et al., 2008; Derory et al., 2010; Homolka et al., 2013; Vidalis et al., 2013).

Recently, the isolation and characterisation of a full-length dehydrin gene (DHN3) and its promoter region in Q. petraea (Vornam et al., 2011) were carried out. The dehydrin genes are putatively involved in plant response to environmental stress and can be useful to examine functional diversity in relation to adaptive variation. The aim of this study was to provide information on the distribution of genetic diversity at DHN3 gene within and among five Quercus species in Romania and to evaluate the potential of this marker for species differentiation in the white oak complex.

\section{Materials and Methods}

\section{Samplingstrategy}

Two populations for each of the five white oak species (Quercus frainetto Ten., Q. petraea (Matt.) Liebl., Q. pubescens Willd., Q. robur L. and Q.pedunculiflora K. Koch) were selected within their natural distribution in Romania (Table 1). The geographical distance between each pair of species ranged from $120 \mathrm{~km}$ (Q.pedunculiflora populations) to $385 \mathrm{~km}$ (Q. pubescens populations). In addition, the Bejan Forest, a mixed stand with four white oak species (Q. frainetto, Q. petraea, Q.pubescens and Q. robur) was sampled. In order to avoid, as much as possible, the sampling of related trees, a minimum distance of $50 \mathrm{~m}$ between individuals was kept in pure species populations. On the other hand, in the Bejan Forest all trees were sampled on an area of 8,6 ha. Morphological identification was performed following Șofletea and Curtu (2007). Evidence of natural hybridization was previously outlined at Bejan Forest (Curtu et al., 2007; Curtu et al., 2015) and individuals with intermediate morphology were categorized as the species they most closely resemble.

\section{Genetic analysis}

After sample collections in the field, plant material (twigs with buds) was transferred to the laboratory and frozen at $-60^{\circ}$ C. Subsequently, DNA was extracted from buds using the Qiagen DNeasy96 and Plant Mini Kit following manufacturer's instructions and the protocol modified by Toader $e$ t al. (2009). The DHN3 marker was amplified using an unlabelled primer pair (5'- TCCATCACTCCCTTCTTCTGA - 3' (forward) and 5' - TGTCGCATTACCAAAACCAG - 3' (reverse)) and a polymerase chain reaction carried out with a Corbett thermocycler. The PCR program included the following steps: (1) denaturation at $95^{\circ} \mathrm{C}$ for $3 \mathrm{~min}$; (2) 30 cycles with a denaturation step at $95^{\circ} \mathrm{C}$ for $40 \mathrm{~s}$, primer annealing at $55^{\circ} \mathrm{C}$ for $1 \mathrm{~min}$ and an elongation step at $72{ }^{\circ} \mathrm{C}$ for $2 \mathrm{~min}$; (3) final elongation at $72^{\circ} \mathrm{C}$ for $15 \mathrm{~min}$. Subsequently, the PCR products and a 50 bp ladder (Promega) were run in 1.5\% agarose gel stained with GelRed (Biotium), by means of horizontal electrophoresis. PCR fragments were run on gel for $10 \mathrm{~min}$ at 50 $\mathrm{V}$ and $100 \mathrm{~min}$ at $90 \mathrm{~V}$. Allele scoring was performed under UV illumination according to the known size of the ladder.

\section{Statistical data analysis}

The following summary statistics were estimated within populations and species, at DHN3 locus, using GenAlEx 6.5 (Peakall and Smouse, 2012): number of alleles (Na), number of effective alleles $(\mathrm{Ne})$, observed heterozygosity $(\mathrm{Ho})$, expected heterozygosity $(\mathrm{He})$ and Wright's inbreeding coefficient $\left(\mathrm{F}_{\mathrm{IS}}\right.$ ). In addition, allelic richness ( $\mathrm{Ar}$ ), a diversity measure that is independent of the sample size (El Mousadik and Petit, 1996; Petit et al., 1998) was computed using the program FSTAT 2.9.3.2 (Goudet, 2001), with a rarefaction of $n=41$ individuals (the minimum population size found in RO-Pet). After a grouping of populations to corresponding species, differences in levels of Ar, Ho, He and Fis between each pair of species were analyzed using the 'comparison among groups of samples', with 1000 permutations for significance test. Potential deviations from the Hardy-Weinberg equilibrium (HWE) at DHN3 gene were tested for each population using Fisher's global exact tests based on Markov chain analysis (Guo and Thompson, 1992) included in GENEPOP 4.2 (Rousset, 2008). Genotypes variation in each population was calculated in MS Excel. A cluster analysis using the unweighted pair group method with arithmetic mean (UPGMA, Sneath and Sokal, 1973) algorithm was performed based on Nei's (1972) minimum genetic distance. Genetic distances and trees were computed using the POPULATIONS 1.2.32 software (Langella, 1999), with 1000 replications for the bootstrap resampling. Subsequently, the dendrogram of the oak populations was created in MEGA 6 (Tamura et al. 2013). For genetic differentiation among oak populations and species, pairwise $\mathrm{F}_{S T}$ 's for all pairs of populations and species, respectively, were computed using the software ARLEQUIN 3.5.2.2 (Excoffier $e t$ al., 2005). The significance of the $\mathrm{F}_{S T}$ statistics was tested by 10000 permutations. The graphical representations of all pairwise $\mathrm{F}_{S \mathrm{~T}}$ were done using a $\mathrm{R}$ function (pairFstMatrix.r, Schneider et al., 2000) implemented in ARLEQUIN via Rcmd. With the same software, a 
584

hierarchical Analysis of Molecular Variance (AMOVA, Excoffier $e t$ al., 1992) was employed to examine the partitioning of genetic variation into components: among groups of populations (species in our case), among populations within groups and within populations. Distributions generated from 10000 random permutations were used to estimate the significances of the various variance components.

\section{Results and Discussion}

\section{Genetic variation within species}

In 967 oaks genotyped at the DHN3 gene, three alleles shared by all five oak species were found. However, only two alleles were present in each population, but with different frequencies according to the species (Fig. 1).

The fragment's length of the alleles were visually estimated after its relative position to the known size of the ladder lines. Thus, the most frequent alleles were labelled as $274 \mathrm{bp}$ and 310 bp and were found in similar proportions ( $48.7 \%$ and $51.0 \%$, respectively) in the overall population ( $n=967$ trees). On the other hand, the third allele, labelled as $346 \mathrm{bp}$, is very rare $(0.03 \%$

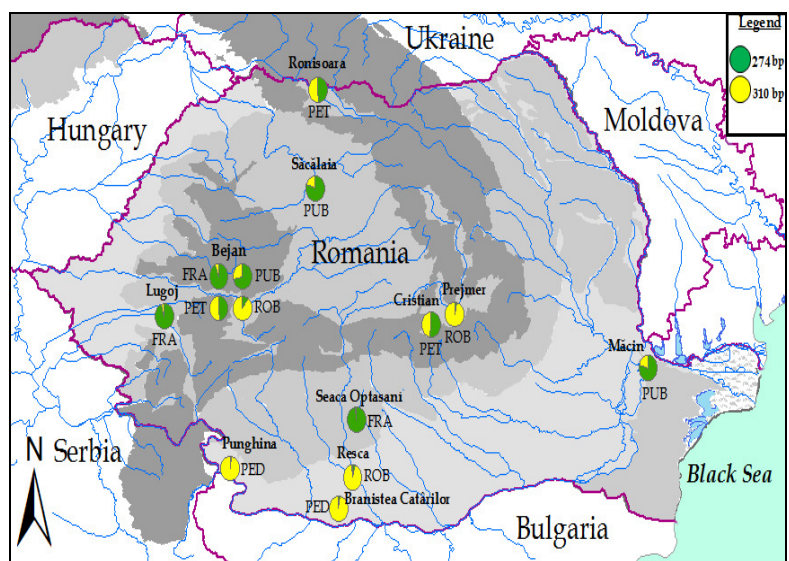

Fig. 1. Allele frequency at DHN3 gene in 10 pure populations and one mixed forest (Bejan) consisting of four oak species. The populations name is displayed at the top of pie chart. The species name is abbreviated as follows: FRA-Q. frainetto, PED-Q. pedunculiflora, PET-Q. petraea, PUB-Q. pubescens, ROB-Q. robur in all samples) and was found only in heterozygous individuals from five populations (Table 2), each one made up of different species. It should be noted that in the initial description of the DHN3 gene in five Q. petraea natural populations, Vornam et al. (2011) found only two alleles: EMBL AM711635 and EMBL AM711636, with PCR fragments length of $656 \mathrm{bp}$ and $620 \mathrm{bp}$, respectively. Thus, the shortest allele had a 36-nucleotide deletion within the coding region and corresponds to the allele denoted $274 \mathrm{bp}$ in this study. The other allele (656 bp) is indicated as 310 bp in our study.

The shortest allele by length (i.e. $274 \mathrm{bp}$ ) is almost fixed (Figs. 1 and 2) in Q. frainetto populations (0.94 - 0.97). The same allele is more frequent than the $310 \mathrm{bp}$ allele in $Q$. pubescens populations $(0.72-0.80)$. On the other hand, the 310 bp allele is most frequent (Figs. 1 and 2) in Q. pedunculiflora (0.96 - 0.98) and Q. robur (0.90 - 0.96) populations. Almost perfect balance between these alleles was found in Q.petraea populations.

The allelic richness (Ar), a genetic parameter without population size bias, showed a small variation among populations (Table 2) and no significant difference among species ( $\mathrm{p}>0.05$ ). On the other hand, higher observed heterozygosity ( $\mathrm{Ho})$ and gene diversity $(\mathrm{He})$ values were identified in Q. petraea and Q. pubescens populations as compared to Q. frainetto, Q. robur and Q.pedunculiflora populations (Table 2).

As a consequence, when averaged across populations within each species, Ho differed significantly $(\mathrm{p}<0.05)$ between $Q$. petraea and Q. frainetto, Q. robur and Q. pedunculiflora, as well as between Q.pubescens and Q. pedunculiflora. The same situation was observed for He, except for the last pair of species. No population showed significant deviations $(p<0.05)$ from genotypic frequencies expected under the Hardy-Weinberg equilibrium (Table 2), although high values of $F_{\text {IS }}$ indicated heterozygote deficit in several populations.
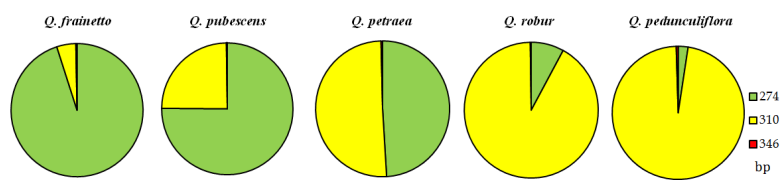

Fig. 2. Allele variation at the DHN3 gene among five oak species in Romania

Table 1. Geographic location of the sampled Quercus populations and of the mixed forest of four oak species

\begin{tabular}{|c|c|c|c|c|c|c|}
\hline Species & Abbreviations & Population & County & Latitude N & Longitude E & Elevation (m) \\
\hline \multirow{2}{*}{ Q. frainetto } & LU-Fra & Lugoj & Timiş & $45^{\circ} 43^{\prime}$ & $21^{\circ} 59^{\prime}$ & 210 \\
\hline & SO-Fra & Seaca Optășani & Olt & $44^{\circ} 43^{\prime}$ & $24^{\circ} 28^{\prime}$ & 310 \\
\hline \multirow{2}{*}{ Q.petraea } & CR-Pet & Cristian & Braşov & $45^{\circ} 38^{\prime}$ & $25^{\circ} 33^{\prime}$ & 730 \\
\hline & RO-Pet & Ronișoara & Maramureș & $47^{\circ} 54^{\prime}$ & $23^{\circ} 58^{\prime}$ & 480 \\
\hline \multirow{2}{*}{ Q.pubescens } & SA-Pub & Săcălaia & Cluj & $46^{\circ} 57^{\prime}$ & $23^{\circ} 56^{\prime}$ & 450 \\
\hline & MA-Pub & Măcin & Tulcea & $45^{\circ} 13^{\prime}$ & $28^{\circ} 14^{\prime}$ & 320 \\
\hline \multirow{2}{*}{ Q. robur } & PR-Rob & Prejmer & Brașov & $45^{\circ} 44^{\prime}$ & $25^{\circ} 44^{\prime}$ & 510 \\
\hline & RE-Rob & Reșca & Olt & $44^{\circ} 10^{\prime}$ & $24^{\circ} 25^{\prime}$ & 80 \\
\hline \multirow{2}{*}{ Q. pedunculiflora } & BC-Ped & Braniștea Catârilor & Olt & $43^{\circ} 53^{\prime}$ & $24^{\circ} 14^{\prime}$ & 110 \\
\hline & PU-Ped & Punghina & Mehedinți & $44^{\circ} 15^{\prime}$ & $22^{\circ} 50^{\prime}$ & 110 \\
\hline \multirow{4}{*}{ Mixed oak forest } & BE-Fra & \multirow{4}{*}{ Bejan } & \multirow{4}{*}{ Hunedoara } & \multirow{4}{*}{$45^{\circ} 51^{\prime}$} & \multirow{4}{*}{$22^{\circ} 53^{\prime}$} & \multirow{4}{*}{280} \\
\hline & BE-Pet & & & & & \\
\hline & BE-Pub & & & & & \\
\hline & BE-Rob & & & & & \\
\hline
\end{tabular}




\section{Differentiation among species}

The DHN3 gene showed a high capability to differentiate among four oak species. However, no significant differentiation ( $p>0.05$ ) was found among populations of the same species (Fig. 3a). In contrast, slight differentiation in the coding region $\left(\mathrm{F}_{\mathrm{ST}}=0.015\right)$ was reported at the same dehydryn gene among five Q.petraea populations from different altitudes in the French Pyrenees (Vornam et al., 2011). Second, no significant differentiation was found between pure $Q$. robur and $Q$. pedunculiflora populations. This result is consistent with the taxonomic relation between these oak taxa, Q. pedunculiflora being a minor species or a subspecies of Q. robur (Curtu et al., $201 \mathrm{lb})$. However, a small $\left(\mathrm{F}_{\mathrm{ST}}=0.028\right.$ and 0.040 , respectively) but significant difference $(\mathrm{p}<0.05)$ was identified between the Q. robur population from the mixed stand (BE-Rob) and the $Q$ pedunculiflora populations (BC-Ped and PU-Ped). Also, all other pairs of populations with different species showed significant genetic differentiation $(\mathrm{p}<0.05)$. In contrast, at species level, all pairwise differentiations were significant $(\mathrm{p}<0.05)$. Q. frainetto and $Q$. pubescens are markedly differentiated from $Q$. pedunculiflora $\left(\mathrm{F}_{\mathrm{ST}}=0.914\right.$ and 0.660 , respectively) and $Q$. robur ( $\mathrm{F}_{\mathrm{ST}}=0.858$ and 0.633 , respectively) at DHN3 locus (Fig. 3b). As expected, the lowest level of differentiation was detected between the most closely related species, Q. robur and $Q$. pedunculiflora $\left(\mathrm{F}_{\mathrm{ST}}=0.020\right)$. However, the latter significant differentiation between this pair of species could be biased by the presence of populations from the mixed stand (Bejan Forest), BE-Rob especially. Indeed, when a complementary differentiation analysis was set up without any population from the Bejan Forest, Q. robur and Q. pedunculiflora could not be significantly differentiated. In addition, the $\mathrm{F}_{\mathrm{ST}}$ values between the remaining pairs of species were similar with those obtained previously, with a slight increase in each case (data not shown).

The high capability of interspecific differentiation at DHN3 gene between almost all pairs of analyzed species suggests that this marker can be an important outlier in the European white oak complex. While only three of the ten pairs of species showed interspecific $\mathrm{F}_{\mathrm{ST}}<0.20$ (Fig. 4b), the majority of pairs of species had an interspecific $\mathrm{F}_{S T}>0.30$. In the Bejan Forest, differentiation among four species was high $\left(\mathrm{F}_{\mathrm{ST}}>0.20\right)$ at two nuclear SSRs (ZAG36 and ZAG96) between some pairs of species (Curtu et al., 2007). However, DHN3 performed better than the afforementioned SSRs, but with a similar $F_{S T}$ value between Q. petraea and Q. robur ( 0.33 vs. 0.31 at DHN3 and ZAG96, respectively). Up to date it is known that a low proportion of the oak genome is highly differentiated (ScottiSaintagne et al., 2004) and few markers can match as outliers. Thus, in a complex genome study with many marker types (AFLPs, SSRs, SNPs, SCARs and isozymes), Scotti-Saintagne et al. (2004) reported only $12 \%$ of total loci (47 out of 389) as outliers, with interspecific $\mathrm{F}_{\mathrm{ST}}>0.018$ between Q. robur and $Q$. petraea. Neophytou et al. (2010) found three nuclear SSRs with interspecific $F_{S T}$ ranging from 0.18 to 0.38 between the same pair of species. The latter F $_{S T}$ value corresponds with the ZAG96 locus, linked with a quantitative trait locus (QTL) associated with petiole length ratio (Saintagne et al., 2004), which showed high interspecific $F_{S T}$ values in other oak studies (Muir and Schlötterer, 2005; Curtu et al., 2007). However, a very small FST value (0.03) was reported at the same locus between Q. robur and Q. petraea populations closed to putative refugial regions (Yücedağ and Gailing, 2013). Recently, Guichoux et al. (2013) identified 60 outliers within a set of 262 SNPs which presented interspecific $\mathrm{F}_{\mathrm{ST}}$ values ranging from 0.27 to 0.93 between $Q$. robur and $Q$. petraea. These values suggest that the $\mathrm{DHN} 3$ gene can also be an outlier among all four species. A similar situation was identified at EST-SSR FIR013 (Lind-Riehl et al., 2014) which displayed a very high interspecific differentiation between Q. rubra and Q. ellipsoidalis $\left(\mathrm{F}_{\mathrm{ST}}=0.668\right)$. This locus is putatively located in COL-1 (CONSTANS-like) gene that could be involved in adaptive divergence and reproductive isolation between these two red oak species. Interestingly, similar allelic variation pattern in $\mathrm{DHN} 3$ and COL-1 genes suggest that few alleles have distinct frequencies according to the species. Thus, both genes might be present in genome regions under divergent selection and could be involved in ecological speciation (Nosil, 2012).

In plants, dehydrins belong to group 2 of LEA (late embryogenesis abundant) proteins and are one of the well studied putative dehydration protective molecules. These types of proteins are produced in response to dehydration during

Table 2. Diversity measures of DHN3 gene within oak populations and species

\begin{tabular}{|c|c|c|c|c|c|c|c|c|}
\hline Population & $\mathbf{N}$ & $\mathrm{Na}$ & $\mathrm{Ne}$ & Ar & Ho & $\mathrm{He}$ & FIS & P_HW \\
\hline BE-Fra & 66 & 2 & 1.13 & 2.00 & 0.12 & 0.11 & -0.06 & 1.000 \\
\hline LU-Fra & 52 & 3 & 1.12 & 2.79 & 0.12 & 0.11 & -0.05 & 1.000 \\
\hline SO-Fra & 53 & 2 & 1.06 & 1.99 & 0.06 & 0.06 & -0.03 & 1.000 \\
\hline Total Fra & 171 & 3 & 1.10 & 2.26 & 0.10 & 0.09 & -0.05 & \\
\hline BE-Pet & 174 & 3 & 2.02 & 2.42 & 0.44 & 0.51 & 0.14 & 0.059 \\
\hline CR-Pet & 49 & 2 & 2.00 & 2.00 & 0.53 & 0.50 & -0.06 & 0.779 \\
\hline RO-Pet & 41 & 2 & 2.00 & 2.00 & 0.39 & 0.50 & 0.22 & 0.210 \\
\hline Total Pet & 265 & 3 & 2.01 & 2.14 & 0.45 & 0.50 & 0.12 & \\
\hline BE-Pub & 114 & 3 & 1.70 & 2.36 & 0.40 & 0.41 & 0.02 & 0.404 \\
\hline SA-Pub & 49 & 2 & 1.48 & 2.00 & 0.24 & 0.32 & 0.25 & 0.089 \\
\hline MA-Pub & 49 & 2 & 1.48 & 2.00 & 0.33 & 0.32 & -0.01 & 1.000 \\
\hline Total Pub & 211 & 3 & 1.60 & 2.12 & 0.35 & 0.37 & 0.06 & \\
\hline BE-Rob & 119 & 2 & 1.23 & 2.00 & 0.19 & 0.19 & -0.03 & 1.000 \\
\hline PR-Rob & 49 & 2 & 1.08 & 2.00 & 0.08 & 0.08 & -0.04 & 1.000 \\
\hline RE-Rob & 48 & 3 & 1.13 & 2.85 & 0.08 & 0.12 & 0.30 & 0.153 \\
\hline Total Rob & 216 & 3 & 1.18 & 2.28 & 0.14 & 0.15 & 0.04 & \\
\hline BC-Ped & 55 & 3 & 1.08 & 2.73 & 0.05 & 0.07 & 0.23 & 0.055 \\
\hline PU-Ped & 49 & 2 & 1.04 & 1.98 & 0.04 & 0.04 & -0.02 & 1.000 \\
\hline Total Ped & 104 & 3 & 1.06 & 2.35 & 0.05 & 0.06 & 0.15 & \\
\hline
\end{tabular}


586

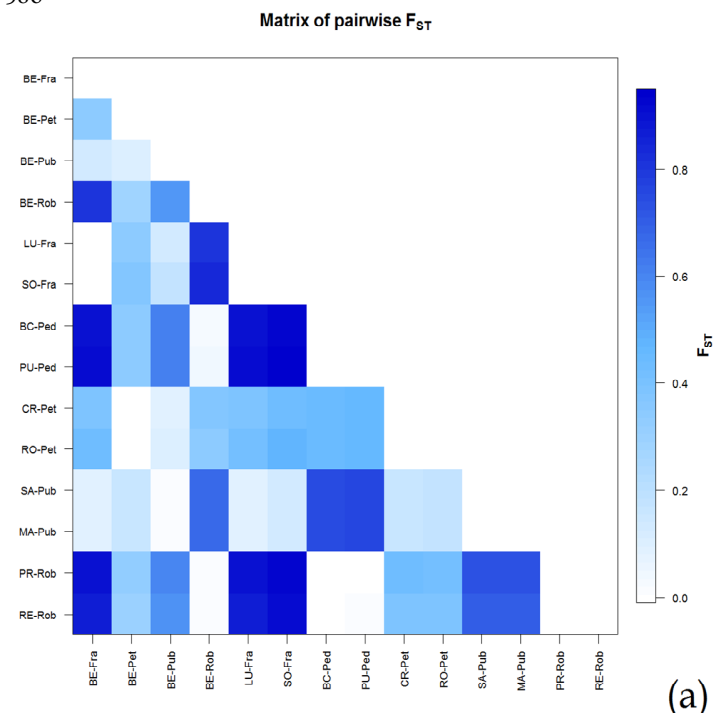

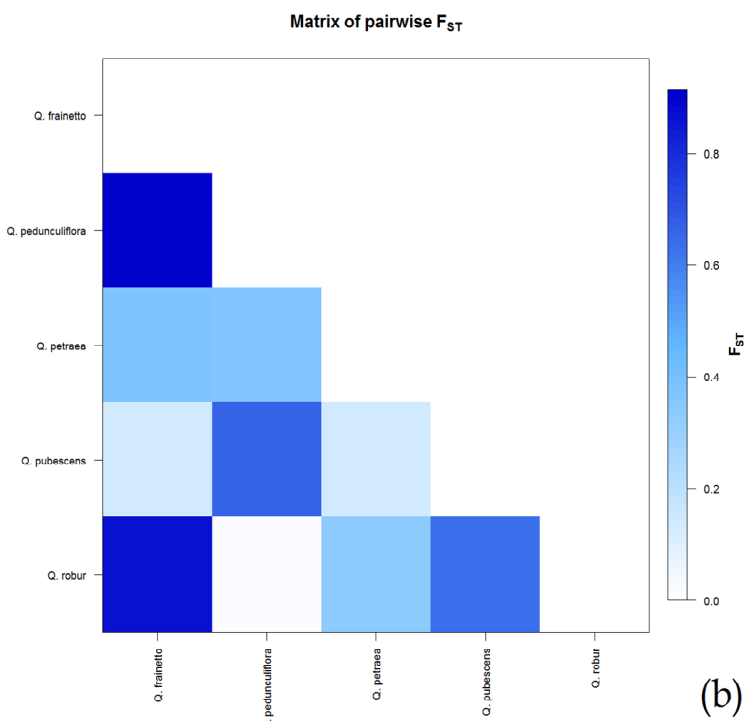

(b)

Fig. 3. Graphic representation of pairwise $\mathrm{F}_{\mathrm{ST}}$ among 14 oak populations (a) and 5 species (b)

environmental stress such as drought (Campbell and Close 1997), low temperatures or freezing (Welling et al. 2004; Yakovlev et al. 2008), and increased salinity (Close, 1997; Rorat 2006). However, the precise function of these genes remains currently unclear. The DHN3 gene can be classified as a $\mathrm{K}_{3}$ dehydrin at Q. petraea (Vornam et al., 2011) that primarily responds to low temperature (Campbell and Close, 1997). In addition, the $\mathrm{K}_{\mathrm{n}}$-type dehydrins are induced by low temperatures and correlate with plants freezing tolerance capacity (Rorat 2006). Thus, homozygote carriers of short allele (i.e. $274 \mathrm{bp}$ in this study) might be less freezing-tolerant than heterozygous or homozyous individuals at longer allele (i.e. $310 \mathrm{bp}$ ) (Vornam et al., 2011). Expanding the correlation at species level it seems that $Q$, frainetto and Q. pubescens are less tolerant to freezing than $Q$. petraea and Q. robur. Indeed, this observation is consistent with the generally accepted ecological requirements of these species. Thus, Q. frainetto and Q. pubescens are found in Southern and Central Europe, while Q. petraea and Q. robur are the most widespread European species, with the latter adapted even to the

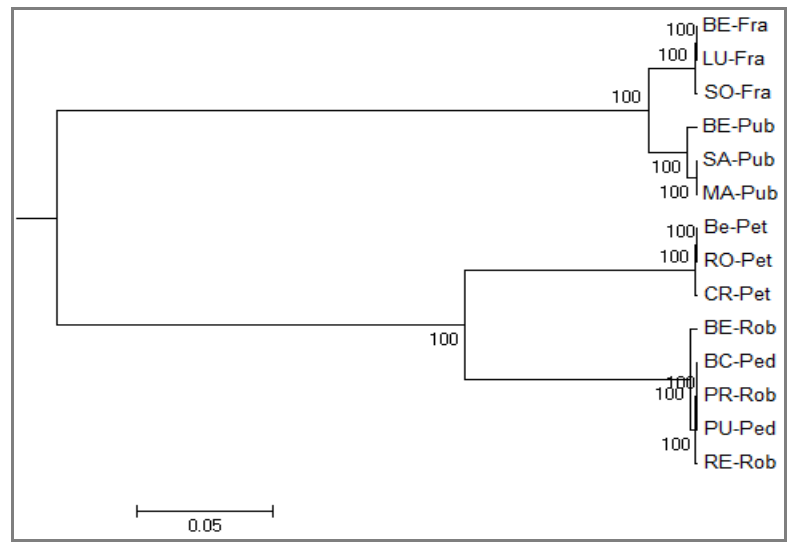

Fig. 4. UPGMA dendrogram based on unbiased estimates of Nei's genetic distances among 14 oak populations at DHN3 gene with 1000 bootstraps. Numbers opposide nodes are bootstrap support values more continental climate of Northeastern Europe. However, further studies on this gene are required to confirm the assumption that $\mathrm{DHN} 3$ gene is involved in freezing tolerance in the Quercus complex. In addition, it should be investigated if dehydrins was involved in the regulation of soluble carbohydrates concentrations, because oak species with higher carbohydrate concentration showed better cold hardiness (Morin et al., 2007).

As a consequence of the lack of significant genetic differentiation between Q. robur and Q. pedunculiflora, the grouping of populations for hierarchical AMOVA was based on the results of pairwise $F_{S T}$ and were: (1) Q. frainetto, (2) Q. petraea, (3) Q. pubescens, (4) Q. robur and Q. pedunculiflora. Thus, AMOVA showed that the percentage of molecular variance is almost equally distributed among species (52.6\% of total variance) and within populations ( $47.3 \%$ of total variance), while the variance among populations within species is very small and not significant $(\mathrm{p}=0.30)$. Similar results were reported in a gene coding for a non-specific NAD-dependent dehydrogenase (Gömöry, 2000), where the interspecific component of variation accounted for $54.3 \%$ of the total gene diversity and $43.5 \%$ of total variation was distributed within populations. In two pairs of Q. frainetto and Q. pubescens populations the largest molecular variance is distributed within populations (92.7\%) and only $6.2 \%$ of the total variance is between species (Curtu et al., 2011a). On the other hand, in a study on three oak species (Q. frainetto, Q. petraea and Q. pubescens), the molecular variance is mostly distributed within the species while a smaller portion of genetic variability was explained by variance among species $(86 \%$ and $14 \%$ of total variance, respectively) (Antonecchia et al., 2015).

The dendrogram constructed using Nei's genetic distances between pairs of populations revealed four main clusters which mostly comprise populations of a single species (Fig. 4), with very high reliability of nodes (100), based on bootstrap resampling. However. Q. pedunculiflora populations were grouped together with Q. robur populations. A relatively small genetic distance was found between $Q$. frainetto and Q. pubescens. Also, a high genetic affinity was noticed between Q. petraea and Q. robur - Q. pedunculiflora group. Similar results were reported by Curtu et al. (2007) in a mixed stand with four oak species, but based on 
isozymes and nuclear SSRs as genetic markers. Thus, these convergent results suggest that the grouping of oak species is maintained irrespective of the particular marker type used.

\section{Conclusions}

The analysis of the DHN3 gene indicates high levels of genetic differentiation among the four major white oak species occurring in Romania. At the same time Q. robur could not be distinguished from its closest relative, the drought-tolerant $Q$. pedunculiflora, which is considered a minor or incipient species. Populations cluster together according to species rather than geographic origin except for Q. robur-Q.pedunculiflora complex. The hierarchical analysis of molecular variance and pairwise $F_{S T}$ point out that $\mathrm{DHN} 3$ is a potential outlier that stands out from the low differentiated genome of European white oak species. Further studies are needed to confirm that the DHN3 gene is responsible with freezing tolerance in Quercus complex.

\section{Acknowledgements}

Iacob Crăciunesc was supported by the Sectorial Operational Programme Human Resources Development (SOP HRD), financed from the European Social Fund and by the Romanian Government under the project number POSDRU/159/1.5/S/134378. We are grateful to GabrielSimion Oltean for the English supervision of the manuscript.

\section{References}

Aldrich PR, Cavender-Bares J (2011). Quercus. In: Kole C (Ed). Wild Crop Relatives: Genomic andBreeding Resources. Springerpp 89-130.

Antonecchia G, Fortini P, Lepais O, Gerber S, Léger P, Scippa GS, Viscosi V (2015). Genetic structure of a natural oak community in central Italy: Evidence of gene flow between three sympatric white oak species (Quercus, Fagaceae). Annals of Forest Research 58(2):1-12.

Barton NH, Gale KS (1993). Genetic analysis of hybrid zones. In: Harrison RG (Ed). Hybrid Zones and the Evolutionary Process. Oxford University Press, Oxford, UKpp 13-45.

Bodénès C, Joandet S, Laigret F, Kremer A (1997). Detection of genomic regions differentiating two closely related oak species Quercus petraea (Matt.)Liebl. and Quercus robur L. Heredity 78:433-444.

Campbell SA, Close TJ (1997). Dehydrins: genes, proteins, and associations with phenotypic traits. New Phytologist 137:61-74.

Close TJ (1997). Dehydrins: a commonality in the response of plants to dehydration and low temperature. Physiologia Plantarum 100:291-296.

CoartE, Lamote V, DeLoose M, Van BockstaeleE, Lootens P, Roldán-Ruiz I (2002). AFLP markers demonstrate local genetic differentiation between two indigenous oak species [Quercus robur L. and Quercus petraea (Matt.) Liebl.] in Flemish populations. Theoretical and Applied Genetics 105:431-439.

Curtu AL, Gailing O, Leinemann L, Finkeldey R (2007). Genetic variation and differentiation within a natural community of five oak species (Quercus spp.).Plant Biology 9:116-126.

Curtu AL, Moldovan IC, Enescu CM, Crăciunesc I, Șofletea N (2011a). Genetic differentiation between Quercus frainetto Ten. and Q.pubescens
Willd. in Romania. Notulae Botanicae Horti Agrobotanici ClujNapoca39(1):275-282.

Curtu AL, Șofletea N, Toader AV, Enescu CM (2011b). Leaf morphological and genetic differentiation between Quercus robur $\mathrm{L}$. and its closest relative, the drought-tolerant Quercus pedunculiflora K. Koch. Annals of Forest Science 68:1163-1172.

Curtu AL, Crăciunesc I, Enescu CM, Vidalis A, Șofletea N (2015). Finescale spatial genetic structure in a multi-oak-species (Quercus spp.) forest. iForest-Biogeosciences and Forestry 8:324332.

Derory J, Scotti-Saintagne C, Bertocchi E, Le Dantec L, Graignic N, Jauffres A, ... Kremer A (2010). Contrasting correlations between diversity of candidate genes and variation of bud burst in natural and segregating populations of European oaks. Heredity 104:438-448.

El Mousadik A, Petit RJ (1996). High level of genetic differentiation for allelic richness among populations of the argan tree [Argania spinosa (L.) Skeels] endemic to Morocco. Theoretical and Applied Genetics 92(7):832-839.

Excoffier L, Smouse PE, Quattro JM (1992). Analysis of molecular variance inferred from metric distances among DNA haplotypes: application to human mitochondrial DNA restriction data. Genetics 131:479-491.

Excoffier L, Laval G, Schneider S (2005). Arlequin (version 3.0): An integrated software package for population genetics data analysis. Evolutionary Bioinformatics Online 1:47-50.

Gailing O, Curtu AL (2014). Interspecific gene flow and maintenance of species integrity in oaks. Annals of Forest Research 57(1):5-18.

Goicoechea PG, Petit RJ, Kremer A (2012). Detecting the footprints of divergent selection in oaks with linked markers. Heredity 109:361-371.

Gömöry D (2000). Gene coding for a non-specific NAD-dependent dehydrogenase shows a strong differentiation between Quercus robur and Quercuspetraea. Forest Genetics75(2):167-170.

Goudet J (2001). FSTAT (version 2.9.3): a program to estimate and test gene diversities and fixation indices. http://www2.unil.ch/popgen/softwares/fstathtm. Accessed 22 May 2015.

Guichoux E, Garnier-Géré P, Lagache L, Lang T, Boury C, Petit RJ (2013). Outlier loci highlight the direction of introgression in oaks. Molecular Ecology 22(2):450-462.

Guo S, Thompson E (1992). Performing the exact test of Hardy-Weinberg proportions for multiple alleles. Biometrics 48:361-372.

Homolka A, Schueler S, Burg K, Fluch S, Kremer A (2013). Insights into drought adaptation of two European oak species revealed by nucleotide diversity of candidate genes. Tree Genetics \& Genomes 9(5):11791192.

Langella O (1999). Populations 1.2.30: population genetic software (individuals or population distances, phylogenetic trees). http://bioinformatics.org/*tryphon/populations/. Accessed 3 May 2015.

Lind JF, Gailing O (2013). Genetic structure of Quercus rubra L. and Quercus ellipsoidalis E. J. Hill populations at gene-based EST-SSR and nuclearSSR markers. Tree Genetics and Genomes 3:707-722.

Lind-Riehl JF, Sullivan AR, Gailing O (2014). Evidence for selection on a CONSTANS-like gene between two red oak species. Annals of Botany 113(6):967-975. 
Manos PS, Doyle JJ, Nixon KC (1999). Phylogeny, biogeography, and processes of molecular differentiation in Quercus Subgenus Quercus (Fagaceae). Molecular Phylogenetics and Evolution 12(3):333-349.

Manos PS, Stanford AM (2001). The historical biogeography of Fagaceae: Tracking the Tertiary history of temperate and subtropical forests of the Northern Hemisphere. International Journal of Plant Sciences 162(S6):S77-S93.

Mariette S, Cottrell J, Csaikl UM, Goikoechea P, Konig A, Lowe AJ, .. . Kremer A (2002). Comparison of levels of genetic diversity detected with AFLP and microsatellite markers within and among mixed $Q$. petraea (MATT.) LIEBL. and Q. robur L. stands. Silvae Genetica 51(23):72-79.

Mayr E (1942). Systematics and the origin of species. Columbia University Press, New York.

McShea WJ, Healy WM, Devers P, Fearer T, Koch FH, Stauffer D, Waldon J (2007). Forestry matters: Decline of oaks will impact wildlife in hardwood forests. Journal of Wildlife Management 71:1717-1728.

Morin X, Améglio T, Ahas R, Kurz-Besson C, Lanta V, Lebourgeois F, Migietta F, Chuine I (2007). Variation in cold hardiness and carbohydrate concentration from dormancy induction to bud burst among provenances of three European oak species. Tree Physiology 27(6):817-25.

Muir G, Schlötterer C (2005). Evidence for shared ancestral polymorphism rather than recurrent gene flow at microsatellite loci differentiating two hybridisingoaks (Quercusspp.). MolecularEcology 14:549-561.

Nei M (1972). Genetic distance between populations. American Naturalist 106:283-292.

Neophytou C, Aravanopoulos FA, Fink S, Dounavi A (2010). Detecting interspecific and geographic differentation patterns in two interfertile oak species (Quercus petraea (Matt.) Liebl. and Q. robur L.) using small set of microsatellite markers. Forest Ecology and Management 259:2026-2035.

Neophytou C, Aravanopoulos FA, Fink S, Dounavi A (2011). Interfertile oaks in an island environment. II. Limited hybridization between Quercus alnifolia Poech and Q. coccifera L. in a mixed stand. European Journal of Forest Research 130:623-635.

Nixon KC (1993). Infrageneric classification of Quercus (Fagaceae) and typification of sectional names. Annals of Forest Science 50:25-34.

Nosil P (2012). Ecological speciation. Oxford Series in Ecology and Evolution, CPIGroup(UK) Ltd, Croydon.

Peakall R, Smouse PE (2012). GenAlEx 6.5: genetic analysis in Excel. Population genetic software for teaching and research - an update. Bioinformatics 28(19):2537-2539.

Petit R, El Mousadik A, Pons O (1998). Identifying populations for conservation on the basis of genetic markers. Conservation Biology 12:844855.

Quang ND, Ikeda S, Harada K (2008). Nucleotide variation in Quercus crispula Blume. Heredity 101(2):166-174.

Rorat T (2006). Plant dehydrins - Tissue location, structure and function. Cellular and Molecular Biology Letters 11:536-556.

Rousset F (2008). GENEPOP' 007: a complete re-implementation of the GENEPOP software for Windows and Linux. Molecular Ecology Resources 8:103-106.
Saintagne C, Bodenes C, Barreneche T, Pot D, Plomion C, Kremer A (2004). Distribution of genomic regions differentiating oak species assessed by QTL detection. Heredity 92:20-30.

Schneider S, Roessli D, Excoffier L (2000). Arlequin Version 2.000: A software for population genetics data analysis. Genetics and Biometry Laboratory, University of Geneva, Switzerland.

Scotti-Saintagne C, Mariette S, Porth I, Goicoechea PG, Barreneche T, Bodenes C, Burg K, Kremer A (2004). Genome scanning for interspecific differentiation between two closely related oak species [Quercus robur L. and Q. petraea (Matt.) Liebl.]. Genetics 168(3):16151626.

Sneath PH, Sokal RR (1973). Numerical speciesomy. The principles and practice of numerical classification. Freeman, San Francisco.

Șofletea N, Curtu AL (2007). Dendrology. Editura Universitatii Transilvania, Brasov(in Romanian).

Tamura K, Peterson D, Peterson N, Stecher G, Nei M, Kumar S (2011). MEGA5: molecular evolutionary genetics analysis using maximum likelihood, evolutionary distance, and maximum parsimony methods. Molecular Biology and Evolution 28(10):2731-2739.

Toader VA, Moldovan IC, Şofletea N, Abrudan IV, Curtu AL (2009). DNA isolation and amplification in oak species (Quercus spp.). Bulletin of the Transilvania University of Braşov2(51):45-50.

Van Valen L (1976). Ecological species, multispecies, and oaks. Species 25:233-239.

Via S (2009). Natural selection in action during speciation. Proceedings of the National Academy of Sciences of the United States of America 106:9939-9946.

Via S, West J (2008). The genetic mosaic suggests a new role for hitchhiking in ecological speciation. Molecular Ecology 17:4334 4345.

Vidalis A, Curtu AL, Finkeldey R (2013). Novel SNP development and analysis at a NADP+-specific IDH enzyme gene in a four species mixed oak forest. Plant Biology 15(s1):126-137.

Vornam B, Gailing O, DeroryJ, Plomion C, Kremer A, Finkeldey R(2011). Characterisation and natural variation of a dehydrin gene in Quercus petraea (Matt.)Liebl. Plant Biology 13:881-887.

Welling A, Rinne P, Viherä-Aarnio A, Kontunen-Soppela S, Heino P, Palva ET (2004). Photoperiod and temperature differentially regulate the expression of two dehydrin genes during overwintering of birch (Betula pubescens Ehrh.).Journal of Experimental Botany 55 (396):507-516.

Wu C (2001). The genic view of the process of speciation. Journal of Evolutionary Biology 14:851-865.

Yakovlev IA, Asante DKA, Fossdal CG, Partanen J, Junttila O, Johnsen Ø (2008). Dehydrins expression related to timing of bud burst in Norway spruce. Planta 228:459-472.

Yücedağ C, Gailing O (2013). Morphological and genetic variation within and among four Quercus petraea and Q. robur natural populations. Turkish Journal of Botany 37:619-629.

Zeng YF, Liao WJ, Petit RJ, Zhang DY (2010). Exploring species limits in two closely related Chinese oaks. PLoSOne 5(11):e15529. 